\title{
正面顔画像からの輪郭特徴抽出
}

\section{Extracting Contours and Features from Frontal Face Images}

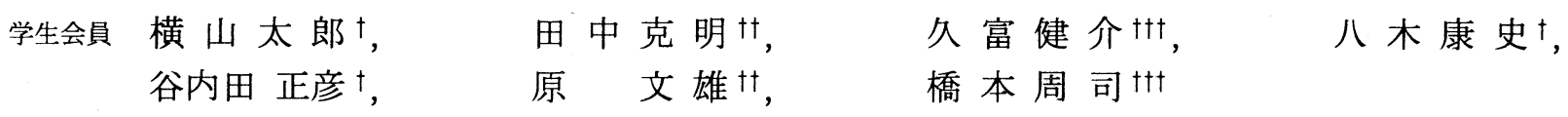

Taro Yokoyama ${ }^{\dagger}$, Katsuaki Tanaka ${ }^{\dagger \dagger}$, Kensuke Hisatomi ${ }^{\dagger \dagger}$, Yasushi Yagi ${ }^{\dagger}$, Masahiko Yachida ${ }^{\dagger}$, Fumio Hara ${ }^{\dagger \dagger}$ and Shuji Hashimoto ${ }^{\dagger \dagger}$

\begin{abstract}
The aim of this research is to locate a face in an input image, then extract the contour lines of the face and the facial features, such as the eyes, mouth, eyebrows and nose in a standard office environment. In this paper we describe a system for extracting the facial features required to reconstruct a $3 \mathrm{D}$ model of a face from a $2 \mathrm{D}$ image. The technique for extracting the eye and mouth contour lines is based on the combination of a quadratic approximation of the edges and an active contour model. 'The technique for face outline contour line relys on the hybridization of a symmetrical active contour model and an elastic contour model with a standard facial shape model. We applied this system to 46 faces and compared the results with manually detected contours: $90 \%$ of the eye and mouth contours and $80 \%$ of the jaw contours and pupil positions matched the hand-prepared contours closely.
\end{abstract}

キーワード：顔画像認識，瞳抽出，輪郭抽出，動的輪郭モデル

\section{1. ま え がき}

コンピュータと人間との自然なコミュニケーションの ためには，従来のような論理情報の伝達だけではなく， 人間の心理的な側面をも考慮したより感性豊かなコミュ ニケーションメデイアの開発が望まれている. そして, 人間の日常生活において顔表情は大変重要な意味を持っ ており，人間と情報システムとの円滑なコミュニケー ションメディアを実現するため, コンピュータによる顔 情報処理の自動化は欠かせないものである ${ }^{16)}$.

このような中, 我々を含む複数の研究機関が連携し, 情報処理振興事業協会における独創的情報技術育成事 業に関わる開発テーマのひとつとして, コンピュータに よる顔情報処理に焦点を当てたプロジェクト「感性擬人 化エージェントのための顔情報処理システムの開発」を

1999 年 1 月 情報処理学会コンピュータビジョンとイメージメディア研究会で発表

1999 年 2 月 22 日受付, 1999 年 7 月 28 日最終受付, 1999 年 9 月 1 日採録 †大阪大学 大学院 基礎工学研究科

（广 560-8531 豊中市待兼山町 1-3,TEL 06-6850-6363)

††東京理科大学 工学部

( $\bar{T}$ 162-8601 東京都新宿区神楽坂 1-3,TEL 03-3268-3905)

††早稲田大学 理工学部

( T 169-8555 東京都新宿区大久保 3-4-1,TEL 03-5286-3233) † Graduate School of Engineering Science, Osaka Univ. (1-3, Machikaneyama, Toyonaka-shi, Osaka 560-8531, Japan) †† Faculty of Engineering, Science University of Tokyo (1-3, Kagurazaka, Shinjuku-ku, Tokyo 162-8601, Japan) †† School of Science and Engineering Waseda Univ (3-4-1, Okubo, Shinjuku-ku, Tokyo 169-8555, Japan)
展開してきた. 本プロジェクトでは, 工学のみならず心 理学や医学などの分野も含めた顔関連分野における共 通の実験用ツールを広く提供することを目的とし，コン ピュータの中に, 擬人化エージェントを合成するための 顔画像の認識・合成に関する顔情報処理システムの構築 を行っている ${ }^{1)}$ 。このシステムでは, カメラなどで撮影 された正面顔画像に対し, 標準的な 3 次元情報を持つワ イヤフレームモデルを張り合わせる方法で, 擬人化エー ジェントを生成している. 従来, このような作業（実顔 画像をワイヤフレームモデルに張り合わせる作業）は, 人 (ユーザ) の手作業により, 各顔器官 (目, 口, 鼻な ど）と顔の輪郭線を正確にワイヤフレームの対応する部 分に合わせる必要があった．特に目や口といった表情変 化や発話に伴い大きく変形する部分や顔の向きによりモ デルとのフィッテング誤差が目立つ顔輪郭は, 正確な位 置合わせが要求され，このような作業はユーザにとって 負担となっている. したがって，簡便で効率の良い擬人 化エージェント生成のためにも, フィッテングの自動化 が望まれる。

そこで本研究では，一般背景のもとで撮影された正面 顔画像から, 顔を発見し, 各顔器官の輪郭線ならびに顔 の輪郭線を自動的に抽出する方法を提案する.

従来, このような輪郭線抽出においては, 顔器官, 顔 輪郭に関しての大局的な性質を利用する方法が多くと られてきた。たとえばYuille らは，目，口に関して，そ 
れらの輪郭形状を 2 次曲線でモデル化したデフォーマブ ルテンプレートと呼ぶ形状モデルを提案している ${ }^{2)}$. 同 様に, 小林らも, 目や口の輪郭線を 2 次曲線近似により 抽出している ${ }^{3)}$. 顔輪郭に関しても, Brunelli らは, 顔 輪郭を楕円と仮定することで, 輪郭線の抽出を行ってい る ${ }^{4)}$ 。一般に楕円や 2 次曲線など，与えるモデルが単純 な場合, 安定に抽出できる反面, 個人や表情による形状 の違いを考慮すると表現できる形状は制限され，正確な 輪郭抽出には適さないものと思われる，一方，自由な輪 郭形状が抽出できる方法として，Kass らにより提案さ れた動的輪郭モデルがあり ${ }^{11)}$ ， 口輪郭や顔輪郭の抽出に 利用されてきたが，初期位置ならびに背景や局所的なノ イズに影響されやすく，一般背景のように，照明や背景 条件が一定でない環境での利用は適さなかった ${ }^{5)}$. それ に対し，我々は，顔の持つ普遍的特徵である左右対称性 を利用し，顔輪郭抽出を正確に行う手法を提案した．し かし，対称性の制約は顔の左右方向の検出には適するが 上下方向に関しては拘束が弱く，対象によっては正確な 輪郭抽出ができなかった．その他，より人の顔器官や顔 輪郭を表現しやすい方法として, Cootes らは，あらか じめ対象の輪郭形状を学習することで, 統計的モデルと して表現する手法を提案している ${ }^{6}$ ．また我々も，弾性 バネにより顔の輪郭形状を表現するモデルを提案してい る ${ }^{14)}$. この方法の場合, 多数の顔画像からバネ係数をあ らかじめ学習することで，学習時の顔に近い形状（標準 顔）の人は, 正確に求められる. しかし, Cootes らのモ デルも，我々の弾性モデルも，教示データに偏りがある 場合や標準顔とは異なる個性的な人に関しては，必ずし も正確な抽出ができるとは限らなかった.

そこで, 本論文では, 複数の形状モデルや手法の統合, 選択的利用により, 口や目の輪郭と顔輪郭を正確にかつ 安定に求める方法を提案する.

以下, 顔輪郭抽出システムの全体概要について述べた 後, 各処理の詳細を示し, 最後に, 手作業により得た輪 郭線と, 提案手法により抽出した輪郭線との比較実験結 果を示す.

\section{2. 顔特徴抽出システム概要}

本システムでは，標準的なオフィス環境での利用を想 定し，一般的な背景の下で正面から撮影された顔画像を 用いる. 被写体は，閉口，開眼時の東洋人とする．処理 内容は, 顔画像から顔を発見し, さらに眉, 目, 鼻, 口 といった顔器官と顔の輪郭線を正確に抽出する. 具体的 には，以下に示す 4 つのステップからなる（図 1）.

(1) 顔の発見と瞳の抽出

瞳・目蓋・眉にかけての鉛直線上の輝度分布パターン を利用し瞳候補の抽出を行う. 抽出された瞳候補が正し いかどうかの検証を，肌色情報に基づいて抽出された顔 領域と瞳候補の位置関係から行う.

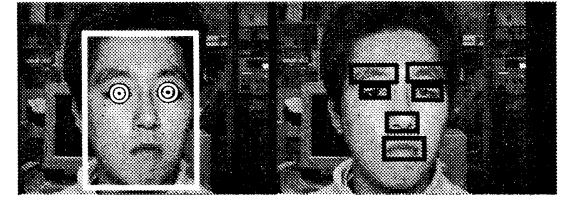

(1)

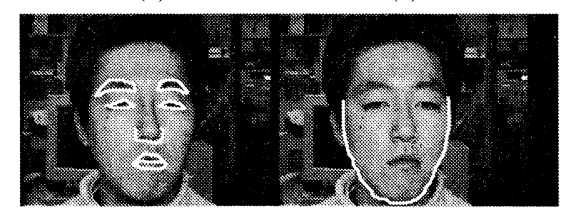

(3) (4)

図 1 顔特徴抽出システム

Facial feature extraction system.

（2）顔器官の概略位置決定

瞳中心点の位置を基準にして, 眉・目・鼻・口の各顔 器官が標準的に含まれる方形領域を設定，その領域内で テンプレート照合を行い, 各顔器官が含まれる最小矩形 領域を決定する.

(3) 顔器官の輪郭抽出

顔器官のうち, 目と口に関しては, 各顔器官の最小矩 形領域内で矩形中心を囲む 2 次曲線を発見し，その曲線 を初期位置とした動的輪郭モデルを利用し正確な輪郭形 状を抽出する，鼻ならびに眉に関しては，テンプレート 照合の結果に基づいた輪郭抽出を行う.

\section{(4) 顔輪郭の抽出}

ここでいう顔輪郭とは, 顔の外形輪郭のうち瞳中心の 左右から顎先までの輪郭線を示す. 各顔器官の概略位置 から顔器官を含む多角形領域を設定し，その位置を初期 位置とし，動的輪郭モデルにより顔輪郭の抽出を行う.

\section{3. 顔の発見と瞳の抽出}

瞳位置の特定のために，本手法では，まず，瞳候補抽 出，顔領域抽出をそれぞれ行う．次に，瞳候補と顔領域 の統合を次の手順で行う．顔領域内に瞳候補のある場合 には, 顔領域内での瞳候補絞り込みを行う. 顔領域内に 瞳候補のない場合には，顔領域に依らず瞳位置を決定す る. 以下, 瞳候補の抽出法, 顔領域の抽出法, 瞳候補と 顔領域の統合の手順を述べる.

\section{1 相互相関による瞳候補の抽出}

瞳候補の抽出では，筆者らの提案した相互相関による 手法 ${ }^{3)}$ を用いることで複数の瞳座標の候補を抽出する. 以下, 瞳候補抽出手法の処理手順を説明する. 瞳から鉛 直線に沿った眉までの顔画像の輝度值分布は, 顔が多少 回転しても瞳の鉛直上方にはまぶた，その上に眉があり， 瞳の黒, まぶたの肌色, 眉の黒という輝度值パターンの 配列は変わらない，そこで，図 2 に示すような瞳中心か ら眉までの鉛直線に沿った輝度值の分布パターンをあら かじめ複数の顔画像から抽出し, 平均化することで, 標 準的な眉から瞳にかけてのテンプレート（基底）を作成 する. そして, この 1 次元テンプレートを用い，相互相 関法により瞳候補を探索する，従来手法では，相互相関 


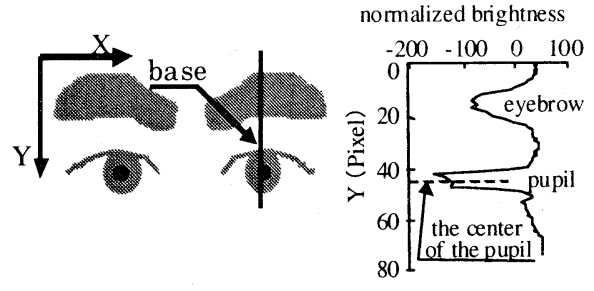

図 2 瞳抽出のためのテンプレートデータ Template data for pupil extraction.

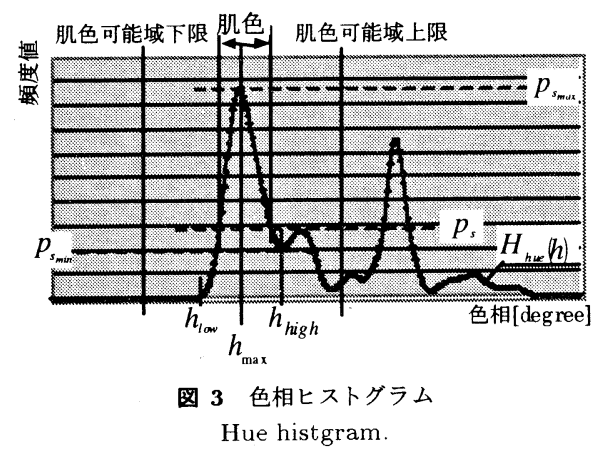

值の上位 2 候補を瞳として選択していた。しかし，背景 が煩雑な場合，必ずしも上位 2 侯補に両目の瞳が入ると は限らない，そこで，本手法では経験的に相互相関值上 位 10 個を瞳候補として選び, 3.3 節の処理により瞳位 置を確定する.

\section{2 肌色情報を基にした顔領域抽出}

一般に顔の色は，たとえ東洋人を対象とした場合でも， 個人差，季節の違いなどにより異なる．そのため, 正確 な肌色モデルをあらかじめつくることは難しい．した がって, 肌色に基づく顔領域の抽出においては, 動的に 肌色を推定する必要がある.

本手法では, 以下に示す手順により顔領域の抽出を行 $5^{7)}$. まず，入力画像から色相のみを取り出し ${ }^{8)}$, その ヒストグラムを生成，平滑化することで色相ヒストグラ 厶を作成する（図 3）。次に，肌色分布は単峰となると 考え, 肌色が分布し得る色相範囲内（図 3 ) で, ヒスト グラムの頻度が最大となる色相 $h_{\max }$ を肌色の中心とす る. なお, 肌色が分布し得る色相範囲に関しては, 実測 データから経験的に求めた. 次に, 最大色相点 $h_{\max }$ を 中心に, 肌色分布が単峰な色相範囲 $\left(h_{\text {low }} \sim h_{\text {heigh }}\right)$ を求 める. そして, この色相範囲上限および下限の頻度値の うち大きい側の頻度值 $P_{s_{\text {min }}}$ と, 最大色相点での頻度值 $P_{s_{\max }}$ とから，(1) 式に示寸割合（頻度值 $P_{s}$ ) までを肌 色範囲と定め顔領域の抽出を行う。

$$
P_{s}=P_{s_{\max }}-0.95\left(P_{s_{\max }}-P_{s_{\min }}\right)
$$

次に, 求められた肌色画像から $\mathrm{x}, \mathrm{y}$ 軸方向に各々 1 次 元射影変換を行い, 平滑化処理を施すことで, 肌色ヒス トグラムを作成する（図 4)．そしてこの肌色ヒストグラ ムに対し計数值が最大となる各々, $\mathrm{x}, \mathrm{y}$ 座標 $x_{\text {max }}, y_{\text {max }}$ を求め, ヒストグラムの最大值 $P_{s x_{\max }}, P_{s y_{\max }}$ のそれぞ れ 0.25 倍, 0.5 倍を閥值 $P_{s x}, P_{s y}$ とし, 最大值周りで闌

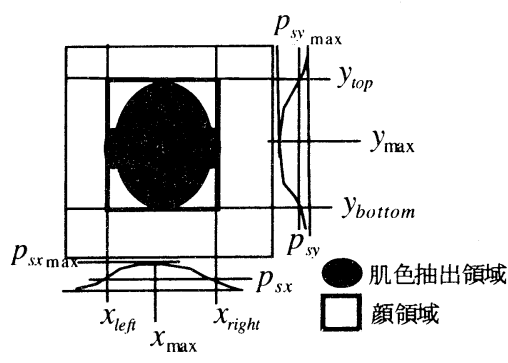

図 4 一次元射影変換による顔領域抽出 Face region extraction by $1 \mathrm{D}$ projection.

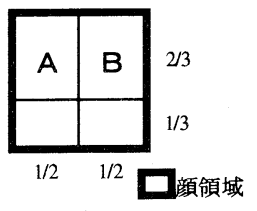

图 5 瞳候補選別マスク

Comparison of relative location between pupil and face region.

值以上の区間 $\left(x_{\text {left }} \sim x_{\text {right }}, y_{\text {top }} \sim y_{\text {bottom }}\right)$ を顔領域と して抽出する.なお，閥值決定のためのパラメータ 0.25 倍と 0.5 倍は, 実験を通して経験的に求めた.

\section{3 瞳位置の確定}

動的肌色抽出によって求められた顔領域の結果と瞳候 補の位置関係から, 正しい瞳の候補の組を抽出する. 一 般に, 両瞳が顔領域に対し, 上下方向や顔の下方に存在 することはない. そこで, 顔領域と両瞳の簡単な位置関 係を制約に瞳位置の確定を行う。実際には, 図 5 に示す ように顔領域の外接矩形に対し, 上部 $2 / 3$ の領域 $\mathrm{A}, \mathrm{B}$ を 各瞳の存在域とし, 前述の瞳候補のうち, $\mathrm{A}, \mathrm{B}$ の領域内 各々で相互相関值が最大となるものを瞳位置として確定 する. ただし， A,B 両領域内に瞳候補が存在しない場合 は，顔領域または瞳位置の抽出失敗の可能性が考えられ るが，経験的に上位 10 候補内には瞳が含まれていたこ とから, ここでは顔領域の失敗と仮定し, 領域外で相互 相関值が最も大きいものを瞳候補とする.このような処 理を行うことで，たとえば瞳候補の上位が片方の領域に 偏る場合, また領域外となる場合でも, 顔領域から下位 の候補を選択することができる.

図 6 は, 相互相関法による抽出結果の一例である.こ の例は, 相互相関值の上位が瞳位置にこない例で, 相互 相関法のみを用いると, 複雑な背景の影響を受け, 瞳と 類似したパターンが上位候補となり，正しい瞳抽出がで きなかったが，本手法では，顔領域の情報（図 7）から 瞳が抽出できる（図 8).ただし，このような場合，相 互相関值が低いため, 上位候補で曈位置が得られる場合 と比べ, 瞳位置の抽出精度は下がる. しかし, 以後の輪 郭抽出のためには瞳内部にあればよく, 本システムの遂 行上では問題ない.

\section{4. 瞳を中心とした顔器官位置関係限定}

本章では, 眉・目・鼻・口の各顔器官を含む領域を抽出 


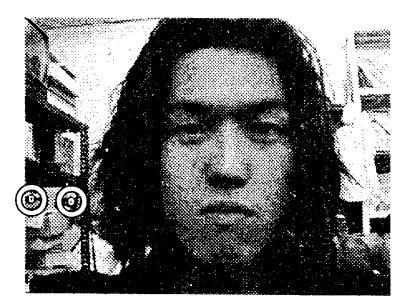

图 6 相互相関法による瞳㹨出失敗例 A wrong result of pupil extraction with cross correration.

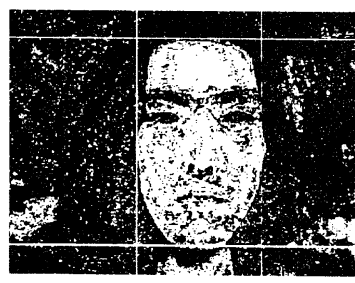

图 7 肌色領域の抽出結果

A result of skin color region.

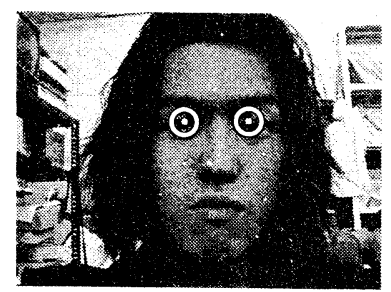

図 8 肌色領域と瞳抽出の併用による顔発見と睡抽出の結果 A result of face region and pupil extraction with proposed method.

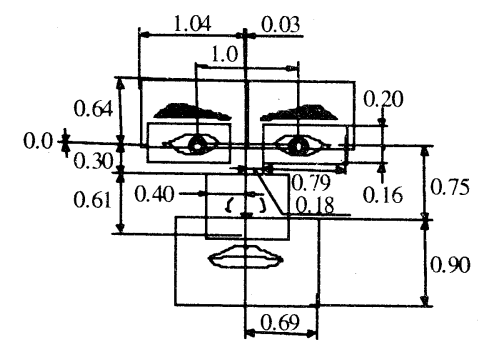

图 9 顔器官存在䈥囲

Search window region for facial features.

する手法について述べる. 本手法は, 顔器官の相対位置 関係がすべての人に対して共通であるという特徴と，各 器官の形状的な特徴を利用することで, 以後の顔器官輪 郭線を抽出するための各顔器官の存在領域を決定する.

\section{1 顔器官領域の相対位置関係}

多少の個人差はあっても，顔器官の大まかな位置関係 は，ほぼ同じと考えることができる，これまで我々は， 30 人の人物の 6 基本表情を表出してもらった顔画像を 用い，すべての人物のすべての表情において眉，目，鼻， 口がそれぞれ含まれる領域を調べ，瞳間距離により正規 化することで顔器官の存在領域の統計モデルを作成し （図 9)，表情認識システムで利用してきた ${ }^{3)}$.しかし，こ のモデルでは存在範囲が広すぎるため，そのままでは正 確な顔器官および顔輪郭抽出には適さない. 本手法では, 大きな表情変化のない顔画像を用いることを前提として いることから，上述の統計モデルに加え平常時の位置特 徵を考慮することで, 各器官の存在領域を限定する.

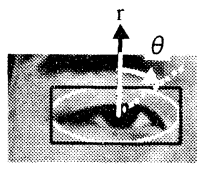

(a)

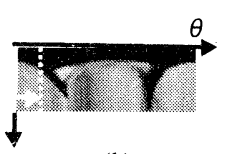

(b)
図 10 目領域

Eye region.

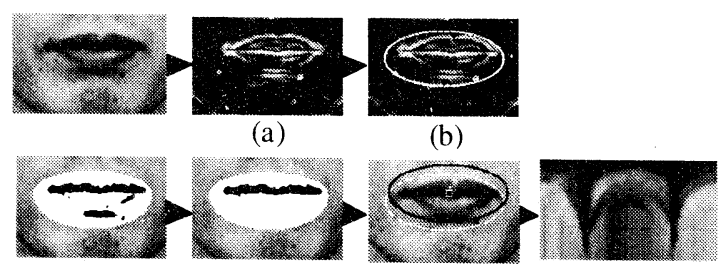

(c)

(d)

(e)

(f)

図 11 口領域

Mouth region extraction and polar coordinate representation.

\section{2 顔器官の存在領域の抽出}

\section{（1）目領域の獲得}

目に関しては，前節の処理により瞳位置をあらかじめ 求めていることで，位置関係に関する個人差は他の器官 と比べ少ない，そこで，顔画像から計測した瞳間距離と 目領域の大きさのデータに基づいて目の存在領域を限定 する. そして，以降の輪郭抽出で必要となる目領域マッ プを作成する，目領域マップとは，図 10(a) に示すよう に存在領域に内接する棈円領域内を瞳座標を中心とす る極座標系に展開したもの（図 10(b)）をさす. 図 10(b) で, 横軸は角度 $\theta$ (3deg/pixel), 綐軸は瞳座標からの距 離 $(r)$ である. なお，楕円の極座標変換の場合，瞳座標 からの距離 $r$ が角度 $\theta$ により異なる，そこで，図 10(b) では，棈円領域外となる部分に，便宜上，各方向での棈 円輪郭部の值を入れている.

\section{（2）口領域の獲得}

口領域に関しては，基準となる瞳位置から離れている こともあり，被写体による位置のばらつきが大きい，そ こで, 顔器官の統計モデルを処理領域として, 以下に示 す口領域抽出処理を施す（図 11）。まず位置検出のため に, 微分処理（図 11(a)）を行い, 平常顔時の口の大き さから経験的に求めた楕円形のテンプレート（棈円内部 がすべて 1 ）を用いたマッチングを行う（図 11(b)）。こ こで口の外形サイズは他の顔器官に比べ大きさが様々で あるため, テンプレートマッチングのみではテンプレー ト中央に口が位置しない場合が多い. 入力画像上で，テ ンプレート内の領域を 2 值化し（図 11(c)），黒色領域を ラベリングする. そして，ラベル付けされた領域中の最 大面積をもつ領域を口領域として抽出し（図 11(d)），そ の重心を口の中心位置とする（図11(e)）。さらに，目の 場合と同様に, 入力画像のうち, 口中心位置を中心とす る楕円テンプレート内を極座標変換することで， 口領域 マップを生成する（図 11(f)）。 


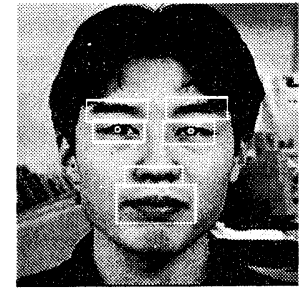

図 12 各顔器官領域

An extracted window region of facial features

\section{（3）眉・鼻領域の獲得}

眉は髪の毛が掛かり，眉の位置すら判断するのが困難 な場合がある，そこで，眉形状を矩形で大まかに近似で きると考え，垂直方向の微分処理を行い，眉の上下の輪 郭を強調し，このエッジ強度画像に対し，統計モデルで 得られた存在範囲を探索域として矩形テンプレート（内 点はすべて1）とのマッチング処理を行い，テンプレー 卜内のエッジ強度の和が最大の座標を求めることで眉の 位置を決める. なお矩形テンプレートの大きさは，平常 顔時の大きさから経験的に求めた.

同様に鼻領域に関しても，鼻頭部の輪郭形状が円弧状 ということから，半楕椆形状のテンプレート（内部がす べて 1 ）を用意することで，鼻の位置を推定する。そし て，鼻輪郭線抽出のために，この鼻の位置を中心とした 極座標変換マップを生成する．図 12 は，4.2 節において 述べた手法により抽出された各顔器官領域の一例である.

\section{5. 顔器官および顔輪郭線の抽出}

本章では，眉・目・鼻・口の各顔器官および顔の輪郭 線を抽出する手法について述べる. 顔器官輪郭線の抽出 は，エッジ列に対する 2 次曲線当てはめを基本とし，特 に精度の高い抽出の求められる目, 口については動的輪 郭モデルを併用する．さらに，顔輪郭線については， 2 つの特性を持つ動的輪郭モデルの混成手法を用いる.

\section{1 顔器官の輪郭抽出}

\section{（1）目，口の輪郭抽出}

筆者らはこれまで, 目と口の輪郭抽出手法について “ 2 次曲線当てはめ法 ${ }^{3)}$ ” と “動的輪郭モデル法 ${ }^{10)}$ ” の 2 つの手法をそれぞれ提案してきた.これらの 2 手法に ついては，その手法の違いから，相反する長所と短所を 持ち合わせていた。 そこで，本稿では両者の長所を生か した形で組み合わせた手法を提案する.

(a) 従来手法の概要

（i） 2 次曲線当てはめ法 目輪郭については, 暗 から明のパターンを持つテンプレートを用い，4 章で作 成した目領域マップ上で相互相関により瞳輪郭を抽出し, 瞳の上下 2 点を基準座標として求める（図 13(a) 白円）. 次に $2 つ$ 基準座標を固定点とし, 上下まぶた輪郭とし て図 15(a) 中, 番号 1 から 4 と示された 4 本の 2 次曲線 当てはめを行う，例えば図 $15(\mathrm{a})$ 番号 1 の近似曲線の場 合, 2 次曲線の右端となる点 $\left(P_{x}, P_{y}\right)$ を固定, 図 15(a)

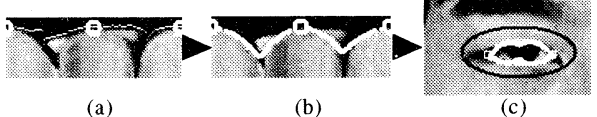

(b)

图 132 次曲線当てはめ法による目輸郭抽出 Eye contour extraction using quadratic approximation.

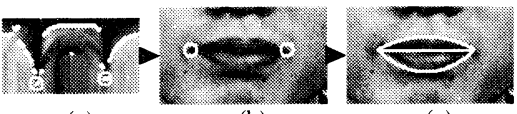

(b)

(c)

図 142 次曲線当てはめ法による口輸郭抽出

Mouth contour extraction using quadratic approximation.

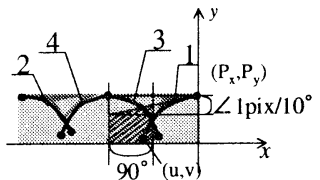

(a)

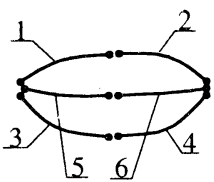

(b)
図 152 次曲線当てはめ位置

The position of quadratic approximated lines for eye contours and mouth contours

に示す斜線領域内で，(2) 式の近似曲線が最も当てはま る（実際には，2 次曲線上の平均輝度が最小となる）位 置 $(u, v)$ を探索する.

$$
y=\frac{v-P_{y}}{u^{2}} x^{2}+P_{y}\left(\begin{array}{c}
-180 \leqq u \leqq-90 \\
0 \leqq v \leqq \frac{1}{10} x+P_{y} \\
P_{x}=0
\end{array}\right)
$$

同様に, 番号 $2 ， 3 ， 4$ に対応する 2 次近似曲線を確定 させた後, 交差するする 2 次曲線 (図 15(a) ならば，番 号 1 と $3 ， 2$ と 4$)$ の交点として端点位置並びに輪郭線 を求める (図 13(b)) . 図 13(c)に 2 次曲線近似による抽 出例を示す.また, 口輪郭についても, 口領域マップ上 で，目と同様の相互相関計算を行うことで，口の両端を 基準座標として求め（図 14(a)），口両端点を決定する （図 14(b)）。両端点を基準とし唇上下部に対応する点列 に対しては, 画像の微分值を用い, 唇中央部については, 画像の暗点を用い，原画像に対して 図 15(b) に示すよう に上唇 2 本, 下唇 2 本, 唇中央 2 本の 2 次曲線近似を行 うことで口輪郭を抽出する（図 14(c)）。

（ii）動的輪郭モデル法 動的輪郭モデル ${ }^{11)}$ は, 滑 らかな曲線を抽出するのに適した表現で，これまで多く の研究者により利用されてきた，一般に，目や口の輪郭 は，2つの滑らかな曲線により表現される. そこで，こ れまで 2 本の動的輪郭モデルを目や口の上下から収束さ せることで，目や口の輪郭を抽出してきた ${ }^{10)}$. 実際は, 図 16 に示寸存在領域の輪郭部（点線上）に各々上下ま ぶたに対応するように動的輪郭モデルを初期配置し, 式 3 に示すエネルギー関数 $E_{\text {snake }}(v(s))$ を最小化すること により輪郭線抽出を行う.

$$
\begin{array}{r}
E_{\text {snake }}(v(s))=\int_{0}^{1} E_{\text {internal }}(v(s))+E_{\text {image }}(v(s)) \\
+E_{\text {control }}(v(s)) d s
\end{array}
$$

ここで, $v(s)$ は輪郭モデル上の点, $E_{\text {internal }}(v(s))$ は輪 郭点列の滑らかさを示す内部エネルギー項, $E_{\text {image }}(v(s))$ 


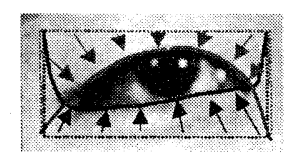

図 16 複数の動的輸郭モデルを用いた目輸郭抽出

Eye contour extraction using multiple snakes.

は輪郭点の画像特徴から得られる画像エネルギー項で

$$
E_{\text {image }}(v(s))=-w_{\text {edge }}|\nabla I(v(s))|^{2}
$$

の様に画像の 1 次微分とした. ここで, $I(v(s))$ は輪郭上 の点 $v(s)$ における画像の輝度值で, $w_{\text {edge }}$ は重み係数で ある. $E_{\text {control }}(v(s))$ は輪郭線の法線方向から加える外部

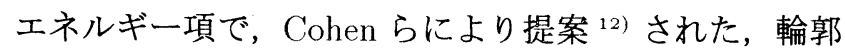
線の法線方向から加わる圧力エネルギ一 $E_{\text {press }}(v(s))$ を 用いた. $E_{\text {press }}(v(s))$ は次のように定義される.

$$
\begin{aligned}
& \frac{\partial E_{\text {press }}(v(s))}{\partial x}=w_{\text {press }} \frac{-v_{s}(s)}{\sqrt{v_{s}(s)^{2}+1}} \\
& \frac{\partial E_{\text {press }}(v(s))}{\partial y}=w_{\text {press }} \frac{1}{\sqrt{v_{s}(s)^{2}+1}}
\end{aligned}
$$

$v_{s}(s)$ は $v(s)$ の 1 次微分值である.このモデルでは, 口 の両端や目尻といった尖端部分は，2本の動的輪郭モデ ルの交点として表現できる.

\section{(b) 提案手法}

提案手法では，上述の 2 手法の特徴を活かすことで, 正確な輪郭形状を安定に求めることを目指す。一般に, 2 次曲線当てはめ法では，2次曲線で輪郭形状を表現す ることから, 複雑な輪郭は表現しきれないが，処理対象 の目領域が大まかに合っていれば，ノイズなどの影響を 受けにくく，安定に輪郭抽出ができるという長所がある. 一方, 動的輪郭モデルは, 高次の曲線として輪郭線を表 現するため, 複雑な曲線も表現可能であるが, 初期位置 の影響を受けやすいという久点がある.

そこで，本手法では，図 17 に示すように 2 次曲線当 てはめ手法により輪郭の概略形状を抽出し, その位置を 動的輪郭モデルの初期位置とすることで顔器官の輪郭線 の抽出をする. 具体的には，まず (i ) と同様に, 目輪郭, 口輪郭を 2 次曲線で近似する（図 $17(\mathrm{a})$ ). 次に, 求めた 輪郭上に動的輪郭モデルを初期配置し（図 17(b)），輪 郭モデルをエネルギー最小となる形状へ変形させる（図 $17(\mathrm{c})$ ). また, 輪郭モデルの外部エネルギ一項に, 2 次 曲線当てはめにより得られた端点からの距離に応じた端 点エネルギー $E_{\mathrm{tip}}(v(s))$ を加えた.

$$
E_{\text {control }}(v(s))=E_{\text {press }}(v(s))+E_{\text {tip }}(v(s))
$$

端点エネルギー $E_{\mathrm{tip}}(v(s))$ は，(8) 式のように定義した.

$$
E_{\mathrm{tip}}(v(s))=-w_{\mathrm{tip}} D_{\mathrm{tip}}(v(s))
$$

ここで, $w_{\text {tip }}$ は重み係数, $D_{\text {tip }}(v(s))$ は 2 次曲線当ては めにより得られた端点までの距離を示している.この端 点エネルギー $E_{\mathrm{tip}}(v(s))$ は, 端点付近での $E_{\text {image }}(v(s))$

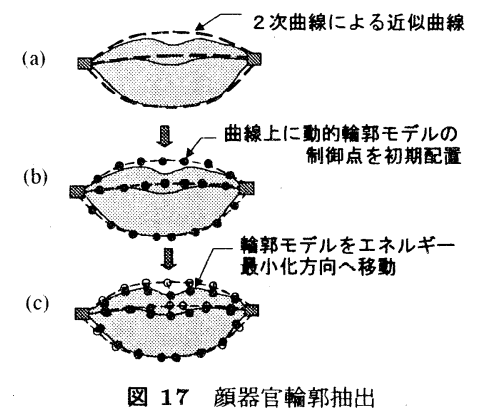

Facial feature contour extraction.

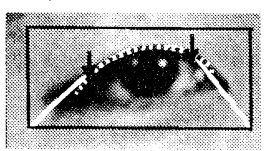

図 18 目輸郭抽出

Eye contour extraction

黒枠は目領域, 点線は 2 次近似曲線, 矢印で囲まれる範囲を利用.

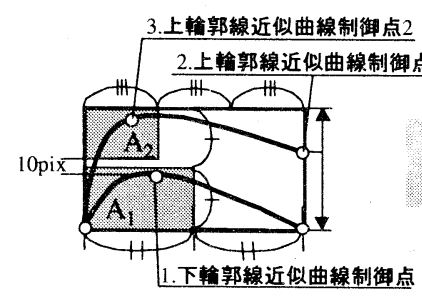

(a)

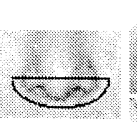

(1)

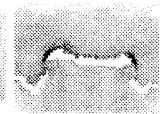

(2)

(b)

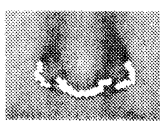

(3)
図 19 眉, 濞翰郭抽出

Eye-brow and nose contour extraction

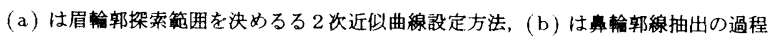

の影響が小さい場合においても，2次近似曲線から求め た端点に引つかかるためのエネルギ一関数である．以上 の動的輪郭モデルが収束した位置を最終的な輪郭抽出結 果とする.

ただし，目輪郭線については，まぶたの影や瞳などの 影響により，2次曲線近似で得られた輪郭線が両端点で 実際の輪郭線より内側に誤る場合がある。このような場 合でも，目の中央付近での輪郭は誤ることは少ない. そ こで, 動的輪郭モデルの初期位置には，2次曲線近似の 結果のうち中央部分 ( 3 分の 2$)$ と, その両端点を目矩 形領域の頂点と結んだ 2 直線上に配置することで，目輪 郭の近傍から動的輪郭モデルの収束を可能にする（図 18 参照).

（2）鼻・眉の輪郭抽出

眉輪郭抽出は，4章において求めた矩形領域内で，眉 上下部の形状を 2 次曲線近似する。近似曲線は, 図 $19 \mathrm{a}$ で示すように，まず，下の輪郭について眉領域矩形左下 点, 右下点と, 図中 $\mathrm{A} 1$ 領域内の任意の点を通る 2 次近 似曲線を描き，次に上の輪郭について，眉領域矩形左下 点と, 眉領域右辺上の任意の点, 図中 A2 領域内の任意 の点を通る 2 次近似曲線を描きその内側領域を眉存在範 囲とする.さらに, 眉存在範囲内を 2 值化, ラベリング し，ラベル付けされた中で最大面積の領域を眉領域とす ることで眉輪郭を決定する. 


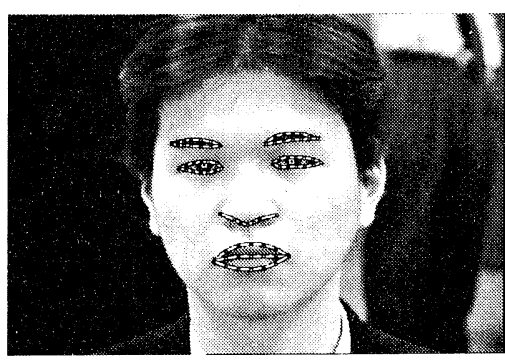

图 20 顔器官輪部抽出結果例

A result of facial feature contour extraction

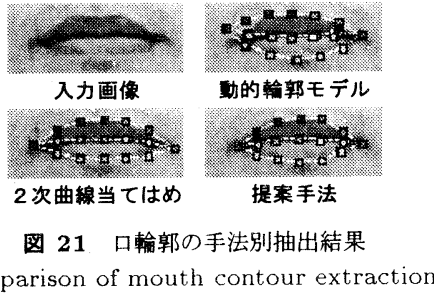

次に鼻輪郭に関しても, 目, 口と同様に 4 章で作成し た半楕円の放射状データマップ（図 19(b)-2)）を用い, 鼻輪郭が比較的暗くなっていることから明（鼻）-暗（鼻 の下の影部）-明（鼻と口の間）という輝度変化パターン を角度軸方向に沿って, 相互相関法により抽出すること で鼻輪郭を決定する.

(3) 顔器官輪郭線の抽出例

以上の処理を用い, 口, 目, 鼻, 眉の各顔器官の輪郭 線を抽出した結果の一例を図 20 に示す. 図 21 は, 特 に精度の要求される口輪郭について，手法ごとの特徴が よく表れた図 20 とは別の対象に対する抽出結果の例で, 従来の動的輪郭モデル法では, 左上の薄いひげに影響を 受け誤った輪郭線を抽出しており，また 2 次曲線当ては めでは，上唇の左右端付近で輪郭に沿わず詰っている. それに対し，提案手法では，ノイズの影響も受けず，実 際の輪郭線に沿った正確な輪郭線の抽出ができている.

\section{2 顔輪郭の抽出}

本手法では，大局的特徵である軸対称性の拘束と，平 均顔から作られた標準顔形状による拘束を持つ 2 種類 の動的輪郭モデルを用意し, 対象となる顔の形状に応じ て，モデルを切り替えることで，顔輪郭を抽出する．以 下，2つの顔輪郭抽出モデルおよび, 提案する顔輪郭抽 出のための動的輪郭モデル混成手法について述べる. な お，動的輪郭モデルを用いるには，初期位置を設定する 必要があるが, 入力画像の背景は, 必ずしも一様なもの とは限らない，そこで，本手法では，初期位置を，図 22 の黒線に示すように顔器官を外側から囲む顔内側に設定 する.

（1）軸対称性拘束を持つ動的輪郭モデル

一般に正面顔の場合, 顔輪郭の普遍的特徵として, 左 右対称性（軸対称性）がある.これまで，われわれは動 的輪郭モデルのエネルギ一項のひとつとして軸対称エネ ルギー項を定義することで，顔輪郭を抽出するための動 的輪郭モデル（以降, 軸対称モデルと呼ぶ）を提案して

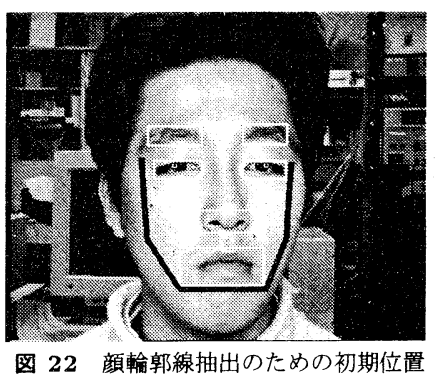

Initial position for extracting face outline contour.

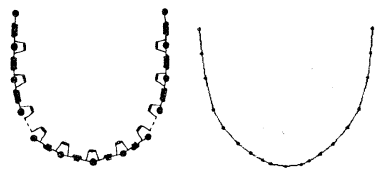

図 23 弾性輸郭モデルと標準顔形状

Elastic contour model and standard face shape.

きた ${ }^{13)}$ 。この軸対称モデルは, Cohen らにより拡張され た動的輪郭モデル ${ }^{12)}$ を元に, 収束時の各タイムステッ プ毎に対称軸を設定し，その軸に対する対称性を崩さな いような拘束を持つモデルである。 このモデルの特徵と して, 個人差によらない収束を期待することができるが, 対称軸に垂直な方向への直接的拘束とはならないために, 顎と首との境界があいまいな人に対しては，顎と首との 境界付近での収束が不安定になりやすかった.

（2）標準顔輪郭形状拘束を持つ顔輪郭抽出モデル

混成手法に用いるもう一方の輪郭モデルは，標準顔輪 郭形状拘束を持つ顔輪郭抽出モデル ${ }^{14}$ ) (以降, 標準顔 形状モデルと呼ぶ）である。このモデルは, 制御点列を バネで結合させた弾性輪郭モデル ${ }^{15)}$ で，あらかじめ用 意した標準顔輪郭形状との形状差からおきる弾性エネル ギーと, 画像特徵から得られる画像エネルギーの和を最 小にすることにより輪郭線を求める方法である.

実際には，顔下部の輪郭モデルは，図 23 左に示すよ うな制御点と隣接 2 制御点間と隣接 3 制御点間に張られ た 2 種類のバネから構成される.このモデルの各辺には, その収縮，拡大に比例する復元力が作用し，隣接する 2 辺の挟角部分にはその角度変化に比例する復元力が作用 する.したがって，あらかじめ定義しておいた標準顔輪 郭形状（図 23 右）の辺，角度をこのモデルの自然長，自 然角度とすることにより, 標準顔輪郭形状との差が大き い状態は，その差を减らすような力を受け，より標準形 状に近い形へと変化する.

この手法の特徵としては，輪郭が部分的に不明瞭な場 合も，それらしい輪郭線を抽出することができる利点が ある反面，標準顔形状から外れた輪郭の場合も標準顔形 状に近い輪郭を出してしまう欠点がある.

（3）最適モデル選択による顔輪郭抽出

軸対称モデルの問題点は, 顔の縦方向の軸についての 対称形拘束のため, 軸と垂直方向の輪郭に対しては拘束 とはならない点である.すなわち，撮影条件や被験者の 特徴により，顎と首の境界が不明瞭な場合，正確な顎と 


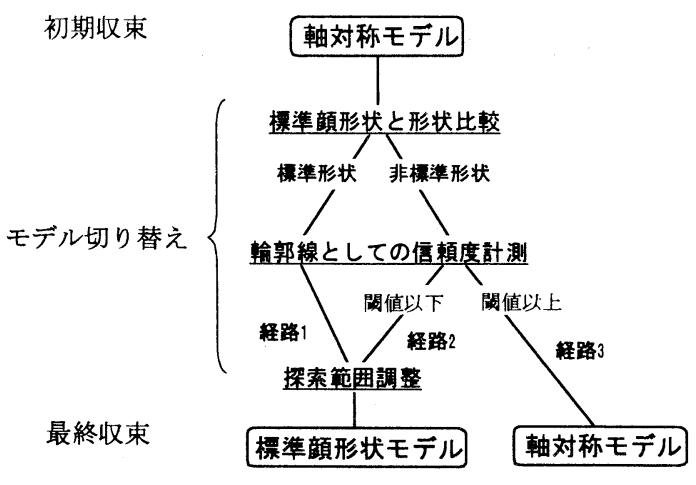

図 24 混成手法処理フロー

Processing sequence of hybrid facial contour extraction method.

首境界の輪郭線を抽出することが困難になることがある. また，標準顔形状モデルの問題点として，標準顔形状か ら離れた顔に対しては誤った収束をする傾向にあること と, 初期位置によっては探索範囲の設定の不具合により 収束結果が変わってくることが挙げられる.

そこで, 本手法では，両モデルの長所を活かし，図 24 のような基準で両モデルを切り替えて用いることで，顔 輪郭線を抽出する. 以下に，処理の流れを示す.

まず，2つのモデルのうち，より大局的な特徽を捉え ている軸対称モデルにより初期収束を行う．次にその結 果に対し，標準顔形状モデルで用いる標準顔形状との形 のずれを測る．標準顔形状モデルに近ければ，標準形状 モデルを当てはめても正しく解が出せると考えられるた め, 最終収束は標準形状モデルで行う (図 24 経路 1).

一方, 初期収束の結果が，標準顔形状から逸脱した形 であった時, その理由として，対象が標準的な顔輪郭を していなかった場合と, 誤った位置に収束しつつある場 合，が考えられる．そこで，初期収束終了時点での顔輪 郭モデルの輪郭点列に対し，顔輪郭としての信頼度を測 り最終収束の方針を決定する．正しい顔輪郭にモデルが 収束している場合，すべての輪郭点で画像エネルギーが 小さくなると考えられることから，信頼度評価の基準は 標準形状モデルの画像エネルギーの一部である輪郭線上 の輝度值の総和を用いた. 信頼度評価值が, 閾值以下の 場合には，軸対称モデルでは誤った収束をしていると判 断し，標準顔形状モデルでの収束を行う（経路 2）。䦭 值以上の場合には, 対象の顔形状が元来標準形から離れ たものであったとして，引き続き軸対称モデルによる収 束を行い，それを最終結果とする（経路 3)．また，標 準顔形状モデルでの最終収束を行う場合（経路 1,2）に は，探索範囲の決定も前述信頼度の大きさに応じて設定 した. なお，輪郭付近は輝度值が低くなっているため， その総和は小さいほど信頼度は高くなる．また，信頼度 の闇值は経験的に設定した.

(4) 顔輪郭線抽出例

2 つの画像に対する軸対称モデル, 標準形状モデルと 提案手法による抽出例を図 25, 図 26 に示す.

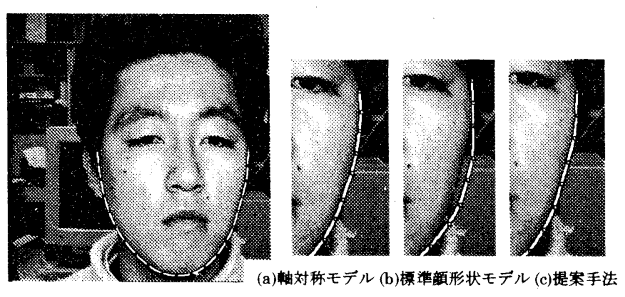

图 25 顔輪郭線抽出例 1

Face outline contour(example 1).

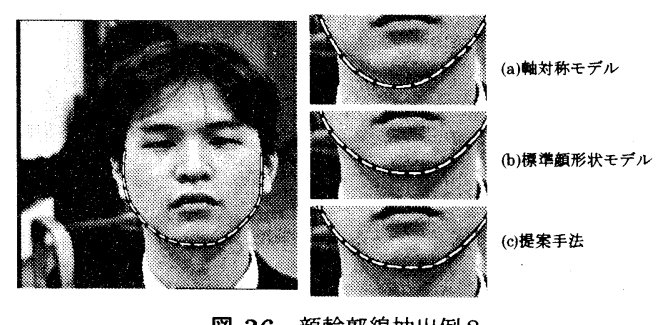

图 26 顔輸郭線抽出例 2

Face outline contour(example 2).

図 25 では, (b) の標準形状モデルが向かって右側のほ ほ付近で失敗している．ほほの外にある背景によってで きたエッジを含めて構成される輪郭線が標準形状に近く なったためと考えられる. 提案手法と, 軸対称モデルで は，問題なく正確な輪郭線を求めることができた，図 26 は, (a) の軸対称モデルが向かって左側の首との境界付 近で失敗している例である，失敗している付近では，軸 対称の拘束が利きにくく，また，かなり連続した区間で 不鮮明となっていることが原因である．このような画像 に対しても，提案手法と，標準顔形状モデルでは，正し い輪郭線を抽出することができている.

\section{6. 総合評価と検討}

本章では, 瞳中心, 目輪郭線, 口輪郭線, 顔輪郭線に ついて, 手入力結果との比較実験を行った．以下各抽出 結果を示す.

\section{1 実験方法}

顔特徴抽出システムの検証実験には, 正面から撮影さ れた，眼鏡，ヒゲなしの東洋人の顔画像 46 枚を用いた. 目・口については, 動的輪郭モデルのみを用いる方法 と, 2 次曲線当てはめの方法，顎については，軸対称性 拘束を持つ動的輪郭モデルと, 標準顔輪郭形状拘束を持 つ顔輪郭抽出モデルとの比較をした．評価のための基準 として, 実験を行なった顔画像上を, 被験者 10 人にマ ウスで指示してもらった. 1pixel は画面上, $0.65 \mathrm{~mm}$ で 表され，顔全体は約 $160 \times 220 \mathrm{~mm}$ の大きさで提示した. 指示してもらった点は, 左右の瞳中心 2 点, 左右の目輪 郭点それぞれ 12 点, 口は 17 点, 顎は 21 点の計 59 点で ある. 瞳中心は指示してもらった点の平均点を基準点と し, 目・口・顔の輪郭は, 指示してもらった点を平均化 し B-Spline 曲線近似を行った曲線を基準輪郭とした。

\section{2 実験結果}

10 人の被験者のそれぞれの入力と基準点および基準線 からの距離を求めた. 各器官ごとに, 求めた距離の平均, 
表 1 手入力誤差 (単位 : pixel) Hand inpuc error.

\begin{tabular}{l|c|c|c|c}
\hline & 瞳 & 目 & 口 & 顔 \\
\hline 平均 & 1.28 & 1.05 & 1.11 & 1.37 \\
\hline 標準偏差 & 0.76 & 0.88 & 0.87 & 1.22 \\
\hline 95 パーセンタイル & 2.24 & 2.73 & 2.82 & 3.39 \\
\hline
\end{tabular}

表 2 目輸郭線抽出結果 (平均, 標準偏差) (単位 : pixel) Estimated error of eye contour extraction (average error, standard deviation).

\begin{tabular}{c|c|c|c}
\hline & 提案手法 & 動的輪郭モデル & 2 次曲線近似 \\
\hline 諤差平均 & 1.20 & 1.40 & 1.33 \\
\hline 標準偏差 & 0.94 & 1.13 & 1.65 \\
\hline
\end{tabular}

標準偏差, 全データの $95 \%$ が含まれる值（95 パーセ ンタイル）を求めた（表 1)．手入力でもある程度の誤 差が起こることから，以降では，正解，不正解の基準を 95 パーセンタイルとし，それ未満を正解，それ以上を 不正解であると考えることにする。

(1) 瞳中心

背景は均一でないにもかかわらず，すべての画像にお いてほぼ正しく抽出することができた，基準点からの距 離は，平均 2.36pixel，標準偏差 2.81pixel であり，内訳 は図 27 のようになった．正解の基準である 95 パーセ ンタイル以下（2.2pixel 以下）のものは $77 \%$ であった.

(2) 目輪郭線

瞳抽出の誤差の大きかったものも含めすべての画像に 対して, 目輪郭線を抽出した結果の基準輪郭線からの距 離は表 2, 図 28 のようになった。平均, 標準偏差とも 他の 2 手法に比べ向上している. 目は比較的はっきりと した輪郭線が表れるため, どの手法でも $90 \%$ の輪郭点 で手入力 95 パーセンタイル以下となった. 2 次曲線当 てはめでは，端点の決定を誤らなければ手入力に非常に 近い輪郭線を抽出できていたが，黒目と白目の境界付近 も目の端点と似たパターンを示す場合があり，端点を誤 り大きな誤差となってしまう場合があった．提案手法で は，そのような大きなミスは起こらなかった。

\section{（3）口輪郭線}

口輪郭線抽出結果の基準輪郭線との距離は表 3, 図 29 のようになった．距離の平均, 標準偏差, その内訳につ いてもすべての区分について，他の 2 手法と比べ向上し ている.また $88 \%$ の輪郭点で手入力 95 パーセンタイ ル $(2.82 \mathrm{pixel})$ 以下となった.

\section{（4）顔輪郭線}

提案する混成手法と，その元となる 2 手法を用いて輪 郭抽出を行った結果を表 4 , 図 30 に示す. 誤差平均も,

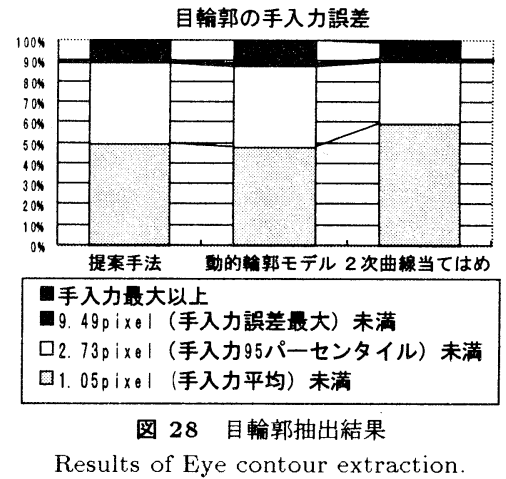

表 3 口輸郭線抽出結果 (平均, 標準偏差) (単位 : pixel) Estimated errors of mouth contour extraction (average error, standarddeviation).

\begin{tabular}{c|c|c|c}
\hline & 提案手法 & 動的輪郭モデル & 2 次曲線近似 \\
\hline 譟差平均 & 1.53 & 2.23 & 2.05 \\
\hline 標準偏差 & 1.50 & 1.87 & 2.37 \\
\hline
\end{tabular}

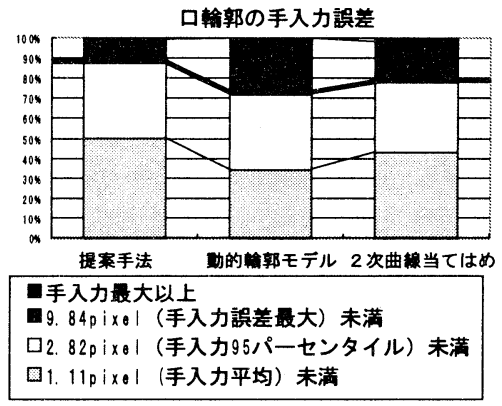

図 29 口輪郭抽出結果

Results of mouth contour extraction.

表 4 顔輪部線抽出結果 (平均, 標準偏差) (単位 : pixel) Estimated error of face outline contour extraction (average error, standarddeviation).

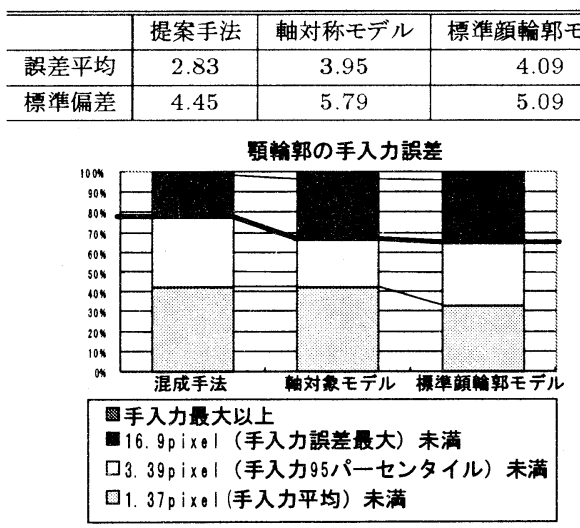

図 30 顔輸郭抽出結果

Results of face outline contour extraction

標準偏差も元となった 2 手法の結果を上回った．また全 体の $78 \%$ が 95 パーセンタイル (3.39pixel) 以下とな り，正解率も元の手法に比べ向上していることがわかる. 軸対称モデルでは，顎と首の境界付近で首まで広がって 失敗することがあり，標準顔形状モデルでは，顎先と口 の中間付近に標準形状の形に収束してしまう場合や背景 によってできたエッジを含めて，構成される輪郭線が標 準形状に近くなったため失敗したものもあった．提案す る手法では，そのようなケースが減り，軸対象モデル， 標準顔形状モデルの欠点を補いあうことができた．また， 実験を行った 46 例中， 39 例が標準形状モデルで最終収 
束を行い， 7 例が軸対称モデルが選択された．上記軸対 称モデルが選択された 7 例中 6 例について標準形状モデ ルでの収束結果よりも良い結果が得られた。このことか ら, 顔の形状が標準形状から外れても，正面顔の大局的 な特徵である軸対称性の崩れることは少なく，本手法の 実用上の妥当性も示されたと考える.

\section{7.むすび}

本研究は, 顔画像を 3 次元モデルにフィッティングす るための特徴点抽出を意識し, より精度の良い顔特徴点 の自動抽出手法を提案し, 顔特徵抽出システムとして実 装した. また, 本手法を複数の被験者の手入力による基 準輪郭線に対する誤差を評価し, 本手法の有効性を示 した. 本研究で対象とした顔特徴点は, 顔画像のモデル フィッティングの目的だけでなく，顔の追跡や個人認識， 表情認識など様々な顔認識のために利用できるものであ ると考えている．本稿で報告した顔特徴抽出システムは， 以下の URLより, フリーウェアとして入手できる. http://www.ipa.go.jp/STC/senshin-dokusou-old.html

本研究を進めるに当たり, 議論を行っていただいた東 京大学 原島博教授, 電気通信大学 金子正秀助教授, 成 蹊大学 森島繁生助教授並びに, AAWG 合成グループの 皆様に感謝いたします．また，本研究グループを運営す る上で協力いただいた (財) イメージ情報科学研究所, 早 稲田大学 青木義満君に感謝いたします. 本研究の一部 は，情報処理振興事業協会 (IPA)「独創的情報技術育成 事業」の一環として行われたものである.

\section{[文献〕}

1）森島繁生, 八木康史, 金子正秀, 原島博, 谷内田正彦, 原文雄, 橋本周司: “顔 の認識・合成のための標準ソフトウェアの開発”，信学技報, PRMU97-282 ,pp.129-136 (1998)

2) A.L. Yuille, P.W.Hallinan and D.S.Cohen:"Feature Extraction from Faces Using Deformable Templates", Int. Jounrnal of Comp. Vision, 8, 2, pp.99-111 (1992)

3）小林宏, 丹下明, 原文雄 : “人の顔の 6 基本表情の実時間認識”，日本ロボッ 卜学会誌学術論文, 14, 7,pp.994-1002 (1996)

4) R.Brunelli and T.Poggio: "Face Recognition: Feature Versus Templates", IEEE Trans. Pattern Anal. and Mach. Intell., 15, 10. pp.1042-1052 (1993)

5) K.Sobottkar,I.Pitas: "Segmentation and Tracking of Faces in Color images", Proc. of 2nd Int. Conf. on Automatic Face and Gesture Recognition, pp.236-241 (1996)

6) T.F.Cootes and C.J. Taylor: "Locating Faces using Statistical Feature Detectors", Proc. of 2nd Int. Conf. on Automatic Face and Gesture Recognition, pp.204-209 (1996)

7）久富健介，橋本周司：“分散処理を用いた顔追跡システム”，第 3 回日本顔 学会大会論文集, p.38 (1998)

8）久富健介，橋本周司：“分散協調エージェントによる顔認識”，信学技報, PRMU97-133, pp.33-38 (1997)

9）工藤力 訳, P.Ekman and W.V.Friesen 著: “表情分析入門”, pp.1-277, 誠信書房 (1988)

10）横山太郎, 吳海元, 谷内田正彦: “動的輸郭モデルを用いた色彩画像からの顔 器官の同定”，画像の認識理解シンポジウム 96 (MIRU96), pp.319-324, (1996)

11) M. Kass, A.P. Witkin and D. Terzopoulos: "Snakes: Active Contour Models", Int. Jounernal of Comp. Vision, 1, 4, pp.321-331 (1988)

12) L. Cohen and I. Cohen: "A fine Element Method applied to New Active Contour Models and 3D Reconstruction from Cross Sections", Proc. 3rd Int. Conf. on Comp. Vision, pp.587-591 (1990)

13）横山太郎，八木康史，谷内田正彦，吳海元：“軸対称性を考慮した顔輪郭の 自動抽出”，信学論 D-II, J 80-DII, 8, pp.2178-2185 (1997)

14) F.Hara,K.Tanaka,H.Kobayashi, and A.Tange:"Automatic Feature Extraction of Facial Organs and Contour", 6th IEEE I.W Robot and Human Communication, pp.386-391 (1997)

15）上田修功, 間瀬健二, 末次康仁 : “弾性輪郭モデルとエネルギー最小下原理 による輪郭追跡手法”，信学誌 D-II，J75-DII，1 pp.111-120 (1992)

16) M.Kaneko and O.Hasegawa: "Processing of Face Images and Its Applications", IEEE Trans. Infomation \& Systems, E82-D, 3, pp.589-600 (1999)
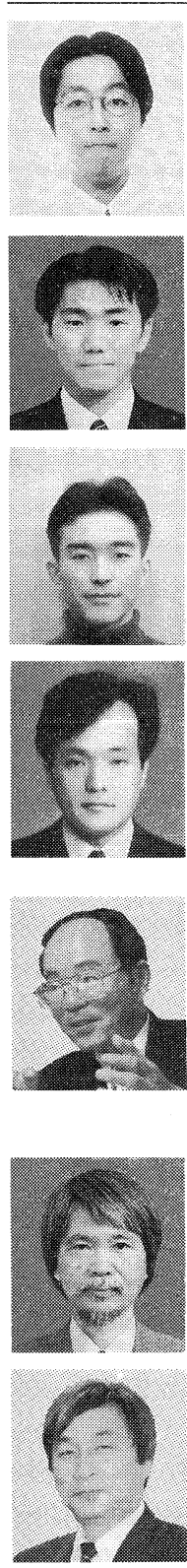

横山まま奇山郎 1996 年, 大阪大学基礎工学部システム 工学科卒業。1998 年, 同大学大学院基礎工学研究科修士 課程修了. 現在, 同大大学院基碟工学研究科博士課程在学 中. 1998 年より日本学術振興会特別研究員. 主としてコン ピュータビジョンの研究に従事.

た思中 克明 1997 年, 東京理科大学工学部機械工学 科卒業. 1999 年, 同大大学院工学研究科修士課程修了. 主 として画像認識の研究に従事。

久さと富健介1997年, 早稲田大学理工学部応用物理 学科卒業. 1999 年, 同大大学院理工学研究科修士課程修 了. 主としてコンピュータビジョンの研究に従事.

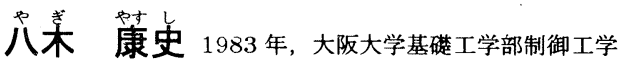
科卒業. 1985 年, 同大大学院修士課程修了. 三菱電機 (株) 産業システム研究所を経て, 1990 年，大阪大学基礎工学部 助手. 現在, 同大大学院基磷工学研究科助教授. 1995 年 1996 年, オックスフォード大学客員研究員. 全方位視覚セ ンシング, 画像理解, 知能ロボットに関する研究に従事. 工 学博士

公らだまさり

学大院工学研究科件 士課程修了. 同大基磷工学部制御工学科助手，助教授を経 て, 現在, 同大大学院基䃈工学研究科システム科学分野教 授. 1967〜1968 年, デンマーク原子力研究所留学. 1972 1973 年, 米イリノイ大にてResearch Associate. 1980 1981 年, 西独ハンブルグ大 Research Fellow. 1982 年, 米ミネソタ大 CDC Professor. コンピュータビジョン, 人 工知能, 移動ロボットの研究に従事. 工学博士.

原文雄 1965 年, 東大工学部機械工学科卒業. 1970 年，同大学院博士課程修了. 1971 年，東京理科大学 工学部助教授. 1983 年, 同教授. 流体関連振動の研究，機 械 システムの異常診断, 水中ロボット，ロボテイクスにお ける形態と知能, 顔ロボット, アクテイブ・ヒューマン・イ ンターフェイスの研究に従事. 工学博士.

橋本占周司 1970 年, 早稲田大学理工学部応用物理 学科卒業. 東邦大学軮師, 助教授, 早稲田大学助教授を経 $\tau$, 現在, 早稲田大学理工学部教授. 画像処理, ヒューマ ンインターフェイス, ロボティックス, 音楽情報処理の研究 に従事. 工学博士。 